\title{
Importance of start-up law for our legal systems
}

\section{Alexandra Andhov}

This chapter seeks to define and delineate in functional terms the subject matter of this book: a start-up and start-up law. It aims to provide a workable concept of a 'start-up' that transcends national boundaries. A start-up as a term is a comparatively recent phenomenon that has emerged in the late twentieth century and has been used more frequently over the past number of years. Its rise is linked with the development of technology and globalization. Despite a growing interest in the subject of start-up law, most lawyers and scholars approach start-ups as any other early-stage company with preconceptions formed by their own domestic company law experience. This can be ambiguous as start-ups as such are very specific types of entities that are not only determined by the period of their existence, but also by their growth acceleration, need for capital and intellectual property (IP) protection as well as agile decision-making processes. Thus, start-ups represent a unique type of an entity that shall be considered in its complexity.

Before diving into the five jurisdictional chapters that are offered in the next part of this book, this chapter discusses the concepts and terminology. It explores separate legal theories and aims to narrow down the term of 'start-up law'. Furthermore, this chapter elaborates on the importance of start-ups in our legal and economic systems for the purposes of achieving innovation, sustainability and development. The chapter starts with a brief overview of historical development of legal personality and legal entity and moves towards an analysis of the distinguishing features of start-ups as a corporate category. Furthermore, the term start-up law is analysed, while focusing on the skills and knowledge components that lawyers often lack yet need to master in order to become the true advisers to start-ups. Lastly, the chapter focuses on the importance of start-ups for our markets and innovation. This section analyses recent interdiscipli- 
nary research and develops several arguments for embracing pro start-up regulatory policies.

\subsection{Journey towards start-ups}

Historically, legal personality and limited liability concepts have developed separately and in different contexts. It is, however, the combination of both principles within one concept that accounts for the success of the modern corporations that have helped to transform the world from the end of the nineteenth century to the world that we know today.

The notion of an association having rights and obligations different and separate from its members was well established under Roman law. ${ }^{1}$ These corporations (universitas) were established primarily as municipal or religious bodies that were able to own property, but as such they were not able to rely on limited liability. ${ }^{2}$ It was only towards the middle of the nineteenth century when the share emerged as a free-standing item of property in its own right and founders started to seek limited liability. ${ }^{3}$ Although members' direct liability for corporation's debt ceased by the end of the seventeenth century, ${ }^{4}$ absent specific provision in the charter, the corporation could still demand a contribution from its members in order to cover the corporation's debts. ${ }^{5}$ By the beginning of the twentieth century, the corporations with separate legal personality, limited liability and freely transferable shares had become the predominant form of business organization across the world. Despite many reforms of corporate and company law during the course of the last century, ${ }^{6}$ often triggered by economic downfalls, corporate scandals and speculations, the basic

1 Carsten Gerner-Beuerle and Michael Schillig, 'Legal and Theoretical Foundations of the Business Corporation' in C Gerner-Beuerle and M Schillig (eds), Comparative Company Law (OUP 2019) 51.

2 FK von Savigny, 'System des heutigen Römischen Rechts' in WH Rattigan, Jural Relations; or, The Roman Law of Persons as Subjects of Jural Relations: Being a Translation of the Second Book of Savigny’s System of Modern Roman Law (Hyperion 1884 (1979)) \$92.

3 Paddy Ireland, 'Capitalism without the Capitalist: The Joint Stock Company Share and the Emergence of the Modern Doctrine of Separate Corporate Personality' (1996) Legal History 41.

4 Edmunds $v$ Brown and Tillard [1669] 1 Lev 237. Cf PI Blumberg, The Law of Corporate Groups: Tort, Contract, and other Common Law Problems in the Substantive Law of Parent and Subsidiary Corporations (Little Brown 1987) 10.

Salmon $v$ The Hamborough Company (1691) 1 Ch Cas 204.

6 Gerner-Beuerle and Schillig (n 1) 56. 
features of the business corporation remain remarkably stable and still define the modern business corporation of today.

The modern corporate law offers a large menu of organizational choices. Entrepreneurs and founders can choose from diverse business forms and structures. National jurisdictions offer a variety of forms, starting with partnerships and continuing with diverse forms of corporations, including limited liability companies, private and public companies or C-Corporations and many others. Corporations and partnerships signify institutional structures that can be found in all Western legal systems. ${ }^{7}$ The term 'partnership' as well as 'company' emphasized the human membership of a group and the personal relationships between the members of the group. ${ }^{8}$ Whereas, by contrast, the term 'corporation' etymologically, refers to the process of turning a group of individuals into a corpus, a word used in Roman law to signify a legally recognized 'collectivity'. ${ }^{9}$ Hence, 'corporation' connotes the separation and emancipation of the legal entity from the individual members. The significance of the distinction later on emanates to various degrees within the process of establishment, rights and obligations of the members as well as the internal governance structures. The later chapters offer an insight into diverse corporate structures that the five jurisdictions offer.

Yet, before reviewing individual corporate forms offered by the selected jurisdictions, it is important to reflect what a 'start-up' is and what distinguishes it from other early-stage small or medium enterprises (SMEs).

\subsubsection{What is a start-up: definition and mind-set}

There is not a generally accepted definition of a start-up. Corporate law itself does not acknowledge a start-up as a specific form of a company. Corporate law remains often focused on the formalistic elements of corporate life, such as (1) legal personality, (2) limited liability, (3) management, (4) nature of the shares, and (5) relationships between stakeholders in a corporation. Many of these elements are crucial for start-ups, but start-ups themselves also represent a specific type of a legal entity that distinguishes itself from other newly established SMEs. In this section, I will

\footnotetext{
Alfred F Conard, Corporations in Perspective (Foundation Press 1976) 137.

ibid.

Gerner-Beuerle and Schillig (n 1) 8.
} 
discuss five specific features and the mind-set of start-ups and portray their uniqueness vis-à-vis other corporate entities.

Starting with definitions offered by dictionaries. According to Merriam-Webster, start-up means 'the act or an instance of setting in operation or motion' or 'a fledgling business enterprise'. The American Heritage Dictionary suggests it is 'a business or undertaking that has recently begun operation'. One of the first defining features of start-ups is their newness. This term speaks not only as to the time since start-up's foundation, but also as to their approach towards business and ideation process. A start-up is a new business that undertakes to solve in a new/ unique manner a problem.

As start-ups pursue the need to solve a problem in a new manner, they attempt to reconceptualize the problem and find a new approach to solving it or find a completely new solution (process or substance). Thus, the second element of start-ups is innovation. Innovation is to be understood in a broad sense, including the development and use of new technology, new product, device, method as well as the application of an innovation process itself. Start-ups are considered to be the disruptors of a market or a business model. However, the essence of start-ups that goes back to 1976, when Steve Jobs and Steve Wozniak founded Apple, is innovation and advancement. Many start-ups are founded not only by entrepreneurs, but also by researchers, economists or industry specialists, who understand the weaknesses and opportunities present in their respective field and thus they undertake to develop a solution or improvement that has been missing. Concerning present start-up activity, there is a lot of relevance in Schumpeter's definition of entrepreneurial activity. He was a firm believer that an entrepreneur is primarily an innovator, ${ }^{10}$ which is the case of start-ups as well. Schumpeter described innovation as encompassing the following: (1) creation of a new good or new quality of good, (2) creation of a new method of production, (3) the opening of a new market, (4) the capture of a new source of supply, (5) a new organization of industry (e.g. creation or destruction of a monopoly). ${ }^{11}$ In Schumpeter's entrepreneurial theory, successful innovation requires an act of will, not of intellect. This component is also present in a start-up

$10 \quad$ Joseph A Schumpeter, The Theory of Economic Development (Harvard University Press 1934) 78.

11 ibid 88-9. 
life, as it is often the execution of the idea rather than the idea itself that is the most important. In Schumpeter's words:

To carry any improvement into effect is a task entirely different from the inventing of it, and a task, moreover, requiring entirely different kinds of aptitudes. Although entrepreneurs of course may be inventors just as they may be capitalists, they are inventors not by nature of their function but by coincidence and vice versa. Besides the innovations which is the function of entrepreneurs to carry out need not necessarily by any inventions at all. ${ }^{12}$

Schumpeter saw economic development as a dynamic process, a disturbance of the status quo, ${ }^{13}$ which also encapsulates the mind-set of start-ups.

The third feature of start-ups is their fast growth tendency. Even if start-ups begin their business adventure as a team of two or three people delivering on a small scale, a start-up by definition aims to grow and scale quickly in order to serve a large market. It is the focus on growth that is unconstrained by geography, which differentiates start-ups from SMEs. A restaurant, a barbershop or a carpenter company in one town is not a start-up, nor is a franchise a start-up. Start-ups' approach model is based on the search for a repeatable and scalable business model, where growth is not only measured by the traditional business terms, as revenue or profit, but also by market share or number of active users.

The fourth element of start-up life is closely connected to the growth and change, which is the funding. Start-ups will obtain within a short period (i.e. two to five years) different forms of funding, such as debt, equity or convertible notes from plethora of investors. Start-ups are bootstrapped at the beginning, which means that founders themselves invest and finance the initial stage of a start-up. Once, the start-up has a solid business plan and a minimal viable product (MVP), the start-up can usually attract external financing, which is usually in a form of an angel investor or a venture capital (VC) firm. As the start-up grows, it will either accumulate more VCs or alternatively can gain some additional debt financing. There are different models and journeys that start-ups can undertake. We elaborate on them in the individual chapters more specifically. Nonetheless, every start-up will have to deal with a need for

ibid.

13 For an analysis of Schumpeter's work, see Robert F Hébert and Albert N Link, A History of Entrepreneurship (Routledge 2009). 
considerable capital and thus raise several rounds of financing and dilute their original ownership until it becomes successful.

We have often heard the motto 'move fast and break things', which became one of the frequent mottos in Facebook and in Silicon Valley. However, the motto is simplistic; it encapsulates the approach and the mind-set of many start-ups. The key feature of start-up life is to be able to move quickly, make decisions and if necessary 'pivot'. That is the fifth feature of start-ups: change. To pivot means to shift or completely change the business model or product itself. Start-ups are often trying to solve a problem or an issue, either in the society or specifically in business, while attempting to use the advantage of being first in solving the problem. Therefore, they need to be agile as they adjust and adopt changes based on constant markets' input, reflection and criticism. Thus, the corporate set-up and internal structure need to reflect this feature of start-ups.

These five elements represent the essence of start-ups in contemporary society, irrespective of the geography or industry. Start-ups have been the initiators of business and technology innovation and development. One could go back to the First Industrial Revolution that has redefined the manufacturing processes in Europe and the United States, where the terms as 'industrialists', 'capitalists' and sometimes 'masters' were used. ${ }^{14}$ John Stuart Mill identified 'capitalists' as one of three productive classes who provided capital and contributed 'no other labour than that of direction and superintendence ${ }^{15}$ Later on, Schumpeter started to use the term 'entrepreneur' and today start-ups encapsulate many of the features and represent the innovation class of 2000s.

Figure 2.1 captures the interrelation of the five elements. The figure depicts the connection between individual components, where a new entity, triggered by innovation, supported with funding is able to grow with an extreme speed across various sectors or geographical markets. If the undertaken business enterprise has been strong and the execution of the idea has proven prosperous, the start-up will scale. Various scenarios

\footnotetext{
14 Robert J Bennett et al., 'Entrepreneurship in Theory and Historical Practice' in Robert J. Bennett et al. (eds), The Age of Entrepreneurship: Business Proprietors, Self-employment and Corporations since 1851 (Routledge 2019) 42.

15 ibid.
} 
reflect start-ups' success. Start-ups can either be sold to a competitor, it can merge with other business or it can become an established publicly traded corporation. However, the entire process is affected by constant change in the innovation process, in the market and in the start-up itself. Even more, in case the market is not receptive of the idea or the execution, the start-up will need to change and pivot or alternatively there will be another 'new' entity.

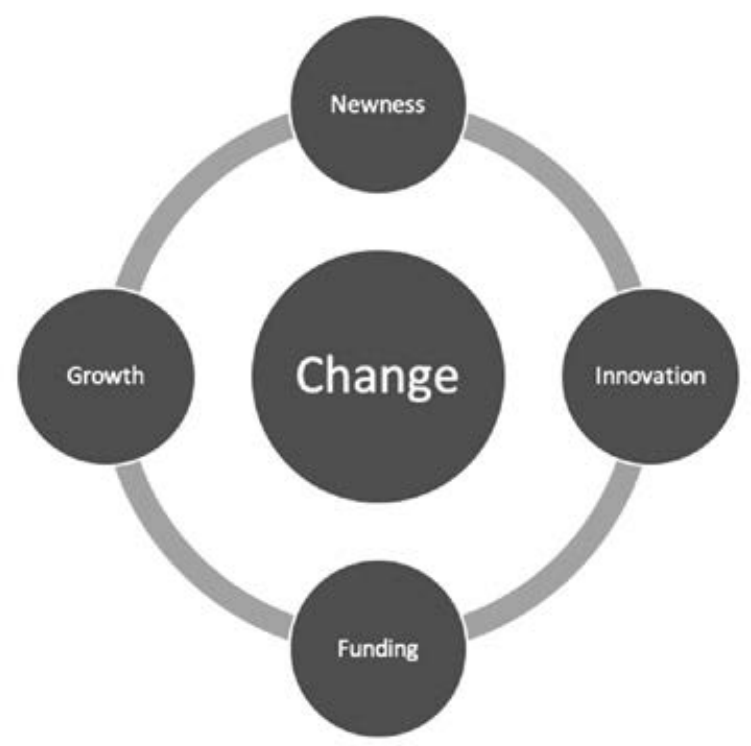

Figure 2.1 Five elements of a start-up

\subsubsection{SMEs and start-ups}

It has become an almost proverbial truism that SMEs form the backbone of practically every economy across the world. ${ }^{16}$ Regional and international entities, such as the European Union (EU), Organization for Economic Co-operation and Development (OECD) or the United

\footnotetext{
16 WTO, World Trade Report 2016: Levelling the Trading Filed for SMEs (WTO Publications 2016) 14-20, https://www.wto.org/english/res_e/booksp_e/world_trade_report16_e.pdf accessed 9 March 2020.
} 
Nations (UN) consider SMEs and entrepreneurship as key to ensuring economic growth, innovation, job creation and social integration in the EU. In the EU, they represent the backbone of the economy - literally, 99 per cent of all of the companies are SMEs, which have over the past five years created around 85 per cent of new jobs and provided two-thirds of the total private sector employment in the EU. ${ }^{17}$ This is not only the case in the EU. SMEs are vital in Asia; according to the OECD Report, the SMEs represent around 97-99 per cent of all enterprises in the Association of Southeast Asian Nations (ASEAN) countries. ${ }^{18}$ The SMEs are a crucial part of the post-2015 UN development agenda to the advancement of sustainable development goals. ${ }^{19}$

However, the focus of governments remains on the larger multinational enterprises (MNEs). Countries have focused at developing international economic law, which mainly regulates the transboundary movement of goods, services and capital, while neglecting the SMEs. ${ }^{20}$ Even though it remains true that MNEs continue to dominate transboundary trade and investment, SMEs, thanks to technology and globalization, are growing outside their domestic environment. Furthermore, due to the financial crisis in 2008, there is a growing realization that opening up international trade and investment to SMEs provides one of the keys to creating more sustained and sustainable economic growth. ${ }^{21}$ SMEs represent the possibility of creating higher levels of employment and have a transformative potential in offering women, young people and discriminated groups significant opportunities. ${ }^{22}$

The regional and international organizations have recognized that the way forward for more sustainable and economically fair trade and economies

17 European Union Commission, 'Entrepreneurship and Small and Medium-sized Enterprises (SMEs)' (European Commission) https://ec.europa.eu/growth/smes_en accessed 9 March 2020.

18 ASEAN, SME Policy Index: ASEAN 2018, Boosting Competitiveness and Inclusive Growth (Report 2018) 26 https://asean.org/wp-content/uploads/2018/08/Report-ASEAN-SME-Policy-Index-2018 .pdf accessed 9 March 2020.

19 United Nations, United Nations' Sustainable Development Goal 8, Target 8.3 (GA Resolution A/69/L.85, 2015) 19-20.

20 Thilo Rensmann, 'Introduction' in Thilo Rensmann (ed.), Small and Medium-sized Enterprises in International Economic Law (OUP 2017) 1-2.

${ }^{21}$ WTO (n 16) 21-4.

22 International Trade Centre, Connect, Compete and Change for Inclusive Growth: SME Competitiveness Outlook 2015 (2015) 14-19 http://www.intracen.org/uploadedFiles/intracenorg/2015SMEComp.pdf accessed 9 March 2020. 
is the support of the SMEs, both locally and globally. The G20 Strategy for Global Trade Growth ${ }^{23}$ endorsed the United Nations' policy objective of promoting more inclusive economic growth by integrating SMEs into the global value chains and opening the possibilities to the global economic markets. Similarly, the European Commission runs various campaigns and projects aimed at promoting a SMEs-friendly environment. ${ }^{24}$

Yet, what does that mean in the context of start-ups and what is the relationship between SMEs and start-ups? Contrary to start-ups, SMEs have an established economic and legal approach towards their definition. Even though there is no unified definition, there are agreed criteria for measuring the 'size' of an enterprise, namely in terms of (1) the number of employees, (2) the turnover volume, and (3) the balance sheet total. ${ }^{25}$ However, there are considerable variables at national, regional and international levels and ongoing discussions as to the inclusion of a new separate category of 'micro-enterprise'. ${ }^{26}$

For the purpose of this book and in the context of the furtherance of SMEs support, start-ups form a category of SMEs, and as such are covered by the policies intended for SMEs, which should not be disregarded by the founders and start-up lawyers. The notion of SMEs includes an extremely wide and diverse spectrum of entities and businesses. As stipulated by Michael Addo, we need to develop qualitative criteria in order to target more precisely the relevant SMEs and to develop more focused regulatory and policy initiatives. ${ }^{27}$ Based on the above definition of start-ups (Section 2.1.1), it is their focus on innovation combined with fast growth and considerable third-party funding that distinguishes them from other SMEs.

Ultimately, start-ups should utilize the benefits and possibilities that various SMEs policies and regulatory initiatives offer in order to promote entrepreneurial activity.

23 G20 Trade Ministers Meeting Statement, 'G20 Strategy for Global Trade Growth' (9-10 July 2016) https://www.wto.org/english/news_e/news16_e/dgra_09jul16_e.pdf accessed 9 March 2020.

24 These projects include the following: The European SME Week, The European Enterprise Promotion Awards as well as various Horizon 2020 and SME Instrument projects.

25 WTO (n 16) 15-16.

26 Michael K Addo, 'Business and Human Rights and the Challenges for Small and Medium-Sized Enterprises' in Thilo Rensmann (ed.), Small and Medium-Sized Enterprises in International Economic Law (OUP 2017) 317.

27 ibid 317-18. 


\subsection{Start-up law}

Start-up companies face unique challenges in the business world if compared with other SMEs. With the founders often focused on product development or research improvement and capital raising, the legal requirements that come with running a start-up and having employees, protecting the product or negotiating the division of equity or designing the data compliance processes are not always properly arranged for. Yet, a failure to address these issues could ultimately result in significant liability for the start-ups as well as for the founders.

The purpose of this book is to address the key issues and provide a comparative source of knowledge and practices that will help to identify some of the key considerations for start-ups and their lawyers. It is the purpose of this book to start shaping a new area of legal practice: the start-up law.

The primary assumption that this book is built on is that start-ups represent a unique type of an early-stage SME, which has distinct features, as described above. Therefore, the start-up law is a field of law that covers the life cycle of a start-up from the moment of ideation until the sale of the start-up, initial public offering (IPO) or bankruptcy. However, the start-up law is not only about legal knowledge, it is also about various skills that lawyers need to embrace and develop. In many respects, the work performed by start-up lawyers resembles the work of a traditional corporate lawyer. They draft contracts, negotiate terms, facilitate transactions and help with various inter-organizational legal matters. However, start-up lawyers have to carry out these tasks in specific circumstances of constant change of the founders and investors, constant change of financing and uncertainty of the nature of the final product or services. In other words, start-up lawyers need to advise a company that does not have the final product, has a constantly developing business plan, has a high fluctuation of employees as well as it undergoing constant changes in management and financing. Furthermore, start-up lawyers represent founders who have little to no experience running a business and thus need to master not only the legal knowledge, but provide insights into business operations or network building. To add to all of this, many contemporary start-ups develop or implement new technology, which means that lawyers need to understand this technology in order to advise on the legal and business aspects associated. 
For the first time, Mark Suchman and Mia Cahill discussed the start-up lawyering in $19966^{28}$ They based their article on numerous interviews with Silicon Valley lawyers in order to draw observations in regard to the knowledge and skills of start-up lawyers. As a follow up, John Coyle and Joseph Green published in 2017 an article with the title 'Startup Lawyering 2.0', ${ }^{29}$ where they assess the practice of start-up lawyers and the differences between 1996 and 2017..$^{30}$ The later work of Coyle and Green depicts numerous differences between the work of start-up lawyers in 1996 in Silicon Valley and 2017 in New York and North Carolina, seeing the contemporary practitioners playing additional roles, including 'transaction cost engineers', 'reputational intermediaries' and 'regulatory compliance experts' ${ }^{31}$ However, there is a bit more in being a good start-up lawyer. In the following sections, a further analysis of the skills and knowledge of start-up lawyers is provided.

\subsubsection{Objective number one: understanding the vision of start-ups}

In theory, any start-up can negotiate and draft all of its contracts without the assistance of outside counsel. Many blueprints of contracts are available online and some legal-tech start-ups have even introduced the possibility of automated individualization of contracts by filling out online questionnaire and thus allowing start-ups to use their resources more efficiently. However, in practice, it is common for start-ups to hire either small law firms or corporate lawyers to prepare the drafts and negotiate the terms. The more scaled and financed a start-up and more important the deal, the more experienced lawyer will be sought.

The experience that the lawyer brings to the table in case of start-ups is not only her ability to draft contracts and to firmly defend the interests of start-ups, but to first and foremost understand the start-up, its business plan, its trajectory and help navigate its legal concerns and relationships. The task of a start-up lawyer is to be aware of the specific nature of the

\footnotetext{
28 Mark C Suchman and Mia L Cahill, 'The Hired Gun as Facilitator: Lawyers and the Suppression of Business Disputes in Silicon Valley' (1996) 21 Law and Soc. Inquiry 679.

29 John F Coyle and Joseph M Green, 'Startup Lawyering 2.0' (2017) 95 North Carolina Law Review 1403.

30 John Coyle and Joseph Green conducted interviews with start-up lawyers in different regions to Suchman and Cahill. They interviewed lawyers from New York City and North Carolina. Overall, they conducted 16 interviews.

31 Coyle and Green (n 29) 1416-22.
} 
start-up, which will differ based on the industry, size and geography. A start-up lawyer needs to anticipate many variables when advising a start-up that stem from the start-up itself, but also from the market and the industry.

As discussed above, a start-up itself does not reflect a specific corporate form. It is in the light of the specifics of the individual start-up that a corporate form shall be chosen, taking into account various present, but also future factors. These will include the number of current founders, possibilities for further partnerships with existing corporations or the need for venture financing. What are the tax incentives, if any? Are there any higher risks of liability involved in the research or development that the start-up is conducting? Will the end product or service be for businesses or retail? How does the business expect to return its profits to its owners? Are there any licences required and do they require specific corporate form? These are some of the considerations that a start-up lawyer needs to take into account even before she advises on the specific corporate form. Yet, a majority of lawyers, when choosing a corporate form, would consider predominantly the limited liability and the initial capital requirement. This strategy is relatable. If a start-up is truly innovative, even the research could expose it to various liability claims. Thus, it is natural that the corporate structure should limit such possibility. Lawyers advising start-ups would often suggest the least expensive corporate form. The logic behind this is also straightforward. According to various studies and reviews, more than 90 per cent of start-ups fail..$^{32}$ Therefore, it is understandable to limit the financial and personal exposure from the beginning. However, this is a very limited perspective and there are much more nuances that need to be considered, which one can do only if one understands the start-up and its vision.

Start-up lawyers should not rely only on prepacked documents that allow their start-ups to incorporate, secure funding from friends and family, and hire employees with the possibility to pay them with stock options. Firstly, some of these documents are already available for free online or even some law firms give them away. More importantly, there is no reflection and value of 'lawyering' in these documents. Despite the fact

2 Neil Patel, ' $90 \%$ of Startups Fail: Here's What You Need to Know about the 10\%' (Forbes, 16 January 2015) https://www.forbes.com/sites/neilpatel/2015/01/16/90-of-startups-will-fail-heres-what-you-ne ed-to-know-about-the-10/\#302e04796679 accessed 10 March 2020. 
that some believe that such 'contracting' is a classic example of transaction cost engineering as they minimize the costs for start-ups, ${ }^{33}$ these blueprint documents will not support start-ups to navigate their business journey and will have close to no value.

\subsubsection{Objective number two: acknowledging the constant change}

When describing the nature of start-ups in the first part of this chapter, the change feature has been placed in the middle of the start-up life. This is the second factor that the lawyer needs to constantly reflect upon and address it in various ways to protect start-ups.

Uncertainty is present in any new business and one could claim that it is present in all businesses. However, the level of uncertainty in start-ups does not only involve the uncertainties connected to the market externalities or possible customer base, but it also covers month-to-month financing, product protection, high employee fluctuation and the need to pivot, as mentioned above. Risk and failure are truly central to day-to-day operations of start-ups, as is shown by the start-up success rate. According to Forbes, nine out of ten start-ups will fail. ${ }^{34}$ Naturally, this figure is only an estimate; there is more and more data that help start-ups navigate their journey more successfully. ${ }^{35}$

One particular area that undergoes rapid changes is the internal governance structure, which not only encompasses the management structure, but also relationships with investors and employees, and their respective representation on the board and in decision-making processes. Start-up lawyers must anticipate and prepare the internal structure for various agency problems, including conflict between founders, founders and investors, the conflict between controlling and minority shareholders as well as conflicts with employees. Moreover, when considering fast-growing start-ups, the positions of shareholders and founders can substantially change within just one or two rounds of financing, which

\footnotetext{
Coyle and Green (n 29) 1411-12.

Patel (n 32).

35 See e.g. Abdo Riani, '11 Surprising and Insightful Statistics about Startups' (Forbes, 24 October 2019) https://www.forbes.com/sites/abdoriani/2019/10/24/11-surprising-and-insightful-statistics-about -startups/\#41df734d6120 accessed 5 March 2020.
} 
can take place within several months. Therefore, wise governance strategies need to be reflected in the light of the present, but also future investor structure and diluted ownership. ${ }^{36}$

The decision-making mechanisms by the founders and later by the board need to be agile and efficient. These mechanisms looks substantially different from those established in family-run businesses or in international corporations. The participants and incentive mechanisms are diverse. Agent incentives play a major role in case of investors, be it an angel investor or a VC firm. Within the framework of the law, market forces play an important role in tailoring the behaviour of corporate agents, such as managers, investors or directors. Despite having fiduciary norms that should guide the duties and loyalties, the start-ups are exposed to external incentive mechanisms that can substantially affect their internal processes. It is common that VC funds invest in various similar start-ups, whereas for their realization of investment, it is sufficient that one of all of the start-ups succeeds. The information models that other corporations live by and navigate their governance models do not operate in same way in early-stage start-up markets. Therefore, having a start-up lawyer who recognizes distinct features of start-up companies and the market is essential for a start-up.

\subsubsection{Objective number three: understanding technology}

Presently, if a lawyer is to advise an early-stage start-up, in order for the lawyer to understand the vision and the market, she will need to understand the innovation that the start-up brings. Often this innovation will be in a form of a development or application of new technology. Thus, naturally the lawyer needs to have at least basic understanding of the technology itself. ${ }^{37}$ This realization has started to nudge law schools to reflect on their curricula and provide future lawyers with the necessary

${ }_{36}$ John Armour et al., 'The Basic Governance Structure: The Interests of Shareholders as a Class' in Reinier Kraakman et al. (eds), The Anatomy of Corporate Law: A Comparative and Functional Approach (3rd edn, OUP 2017).

37 Some even stipulate an obligation to being technologically competent. See John Browning, 'The New Duty of Tech Competence in Texas: Staying Ethical and Competent in the Digital Age' (2019) 89 The Advocate 26; or Kristin L Yokomoto, 'Ethical Duty of Technology Competence' (2019) 61 Orange County Lawyer 66. 
technological knowledge. ${ }^{38}$ The same is applicable for summer schools, LLM programmes and professional education seminars that are being offered to already practising lawyers. ${ }^{39}$ This development is not only due to the high increase in the technological innovation in start-up sector over the past decade, but also due to the automation in legal services.

In 2017, McKinsey \& Company published a research report that asserted that 'bold, tightly integrated digital strategies' will serve as the differentiator between the organizations that thrive and survive and those that languish and cease to exist. ${ }^{40}$ Despite that, law firms only slowly reflect on this development; being one of the most conservative industries, some have recognized the 'sweeping force of technology' as a serious threat to commoditization of legal services. ${ }^{41}$ In other words, legal services will need to embrace technology within their own processes and value delivery. As mentioned above, the start-up lawyers' value will be in the knowledge and specifications rather than in standardized contracts. ${ }^{42}$ Lawyers' activities that can be automated, will be and the industry will embrace legal algorithms. ${ }^{43}$ What will remain is the knowledge of law, industry and technology and the ability to apply this knowledge with skills for the benefit of a client.

38 At the Faculty of Law of the University of Copenhagen, there are already numerous courses offered that focus on technological knowledge and skills. The list is accessible online at: https://kurser.ku.dk/ $\# \mathrm{q}=$ technology\&education $=$ \&programme=\&volume=\&departments=\&faculty=FACULTY_0006\& studyBlockId=\&teachingLanguage $=$ \&period $=\&$ schedules $=\&$ studyId $=\&$ openUniversity $=0$ \&searched $=1$ accessed 10 March 2020 .

39 The legal education needs to undertake various changes. For more see Hilary G. Escajeda, 'Legal Education: A New Growth Vision Part I - The Issue: Sustainable Growth or Dead Cat Bounce? A Strategic Inflection Point Analysis' (2019) 97 Nebraska Law Review 628; Richard Susskind, Tomorrow's Lawyers: An Introduction to Your Future (2nd edn, OUP 2017).

40 Jacques Bughin et al., 'The Case for Digital Reinvention' (MCKINSEY \& CO, February 2017) https://www.mckinsey.com/business-functions/mckinsey-digital/our-insights/the-case-for-digital -reinvention accessed 10 March 2020.

${ }^{41} \quad$ Frank Pasquale, 'A Rule of Persons, Not Machines: The Limits of Legal Automation' (2019) 87 George Washington Law Review 1.

42 Caitlin Moon, 'Delta Model Lawyer: Lawyer Competencies for the Computational Age' (MIT Computational Law Report, 6 December 2019) https://law.mit.edu/pub/deltamodellawyer accessed 10 March 2020.

43 Alex Pentland, 'A Perspective on Legal Algorithms' (MIT Computational Law Report, 6 December 2019) https://law.mit.edu/pub/aperspectiveonlegalalgorithms accessed 10 March 2020. 


\subsection{Innovation and sustainability: reasons for supporting pro-start-up regulatory environment}

Governments play a key role in creating a supportive regulatory environment that bolsters entrepreneurship and innovation by adopting regulatory and policy measures that promote dynamic, inclusive and sustainable businesses. A pro-entrepreneurial regulatory environment that encourages entrepreneurs and start-ups to engage in new business ventures is essential. Governments can either reduce or amplify diverse barriers that pose challenges for new businesses and innovation endeavours. Reducing business entry costs such as business registration, minimum capital requirements, and various licensing fees for start-ups can enhance the entrepreneurial regulatory environment and help stimulate the development of new start-ups in various sectors. In a favourable regulatory and tax environment, start-up businesses will be more active and successful. Various empirical studies and research show that regulatory frameworks represent important factors influencing the innovation activities of companies, industries and entire economies. ${ }^{44}$

In this section, the discussion focuses on the regulatory approach towards innovation as well as technology and sustainability, while reflecting on the dynamics of regulatory competition. Part II of this book offers start-up law in five jurisdictions that have in some respects similar and in some respects dissimilar approaches towards regulatory issues. The importance of this section lies in analysing the importance of regulatory competition and recent entrepreneurship policy recommendations from the United Nations Conference on Trade and Development (UNCTAD) and reflecting on the most recent trends.

\subsubsection{Innovation and collaboration}

Innovation has many forms. Despite our contemporary discussions around innovation as being something extraordinary and pertinent to

44 See e.g. Knut Blind, 'The Impact of Regulation on Innovation' in Jakob Edler et al. (eds), Handbook of Innovation Policy Impact (Edward Elgar 2016); Yafit Lev Arez and Katherine J Strandburg, 'Regulation and Innovation: Approaching Market Failure from Both Sides' (2019) https://papers.ssrn .com/sol3/papers.cfm?abstract_id=3462522 accessed 10 March 2020. 
our times, we have been innovating ourselves throughout our existence. ${ }^{45}$ Human creativity, inventiveness and adaptability are in the centre of our development and life. Machiavelli wrote about innovation in The Prince in $1513^{46}$ and Schumpeter, born in Austria-Hungary, conquered Harvard as the father of innovation studies. ${ }^{47}$ Some consider the First Industrial Revolution (1760-1850) a story of innovation that continues to keep an important message about collective thinking, collective work and innovation. ${ }^{48}$ Contemporary innovation is also multi-faceted as well as the innovation scholarship. ${ }^{49}$ Some of the innovation is anchored in new technology, some in new processes and some in new approaches to problem-solving.

Different structures of our society promote innovation, including educational institutions, public authorities as well as businesses themselves. We are trying to find solutions to complex problems as climate change, access to justice, access to health care or more efficient financial system for all. Start-ups and entrepreneurs see a commercial opportunity in finding the solution and distinguishing themselves from other competitors. Schumpeter himself initially believed that succeeding in innovation demanded a visionary individual entrepreneurs, capable of overcoming societal inertia. ${ }^{50}$ However, several years later, he recognized that innovation was more often a product of a cooperative process, which needed to be studied beyond the individual level. ${ }^{51}$ Therefore, we observe that start-ups that succeed comprise of successful teams rather than individuals.

Yet, how can the society and the regulators support this approach to collaboration and enhance the success of innovation, as it is due to the

45 Cristie Ford, 'Innovation and the State: Finance, Regulation and Justice' (CUP 2017) 1-23.

46 Niccoló Machiavelli, The Prince (CreateSpace Independent Publishing Platform 2013).

47 Joseph Schumpeter, Capitalism, Socialism and Democracy (Harper \& Brothers 1942); Schumpeter's work has been discussed in the first part of this chapter. His work remains relevant in entrepreneurship studies even today.

48 Ford (n 45) 145-7.

49 Clayton Christensen defined the 'disruptive' innovation. He described multiple examples in which small, initially simple and non-threatening changes (like the incursion of staticky transistor radios into big stereo-makers' turf, or the incursion of low-grade steel mini mills turned into global enterprise of US Steel). Clayton M. Christensen, The Innovator's Dilemma: When New Technologies Cause Great Firms to Fail (Harvard Business School Press 1997).

50 Schumpeter (n 47).

51 Jan Fagerberg, 'Innovation: A Guide to the Literature' in Jan Fagerberg et al. (eds), The Oxford Handbook of Innovation (OUP 2005) 1-26. 
innovation that economies experience development and growth? What do we know about innovation in addition to the importance of compatible teams? In 1997, Christopher Freeman and Luc Soete distinguished between two types of innovation: 'radical' and 'incremental'. ${ }^{52} \mathrm{~A}$ radical innovation is about big, paradigm-shifting, transformative change: electricity, the Internet or an electronic car. An incremental innovation is a small, seemingly mundane improvement based on learning through experience: the discovery of the electron or use of data communication. Many radical innovations are based on several incremental innovations. This element of innovation has become recognized within the regulatory framework, through IP law, where even the smallest innovations and discoveries are recognized and valuable.

The innovation literature has observed the importance of personal communication and networks. ${ }^{53}$ Innovation emerges through social interaction, which is recognized by corporations, universities as well as governments. They tend to cluster geographically and support personal interaction. Recent innovation scholarship has analysed how certain 'network properties' promote development and diffusion of innovation. ${ }^{54}$ Across the entire globe, we see the constant formation of new hubs, start-up labs and other cluster organizations..$^{55}$ Many governments, universities and corporations have invested heavily in accelerator programmes and innovation funding. ${ }^{56}$ All these policy decisions have been

52 Christopher Freeman and Luc Soete, The Economics of Industrial Innovation (3rd edn, MIT Press 1997).

53 Bjørn T Asheim and Meric S Gertler, 'The Geography of Innovation: Regional Innovation Systems' in Jan Fagerberg et al. (eds), The Oxford Handbook of Innovation (OUP 2005) 292-4.

54 David Strang and John W Meyer, 'Institutional Conditions for Diffusion' (1993) 22 Theory \& Society 487-511.

55 See e.g. Jared Hecht, 'Where to Start (or Grow) Your Startup outside the Tech Hubs' (Forbes, 20 November 2019) https://www.forbes.com/sites/jaredhecht/2019/11/20/where-to-start-or-grow-your -startup-outside-the-tech-hubs/\#5e05ef14876d accessed 12 March 2020; Jonathan Moules, 'Start-ups fall for Barcelona's Tech Hub Allure' (Financial Times, 10 December 2019) https://www.ft.com content/6ec41804-ce33-11e9-b018-ca4456540ead accessed 12 March 2020; 'In Focus: The World's Best Start-up Hubs' (Virgin) https://www.virgin.com/entrepreneur/focus-worlds-best-start-hubs accessed 12 March 2020.

56 Arthur D Little, 'The Growth Accelerator Managing Innovation Based Growth' (2013) https://www .adlittle.com/sites/default/files/viewpoints/The_Growth_Accelerator.pdf accessed 10 March 2020. The analysis describes several factors within the 'Growth Accelerator Framework', including (1) growth roadmaps; (2) pilot solutions; (3) organization and processes; (4) culture and change leadership; and (5) capabilities and tools. 
undertaken with the vision of enhancing entrepreneurship and innovation, and successfully so.

One of the last elements that innovation literature since Schumpeter recognizes is the 'diffusion of innovation' ${ }^{57}$ As Freeman and Soete have stipulated, what matters in terms of major economic effects is not the date of the basic innovation, but the diffusion of this innovation..$^{58}$ Schumpeter described this as the 'swarming' process, when the profitable potential is being realized, ${ }^{59}$ which is the elemental both for the start-up as well as the economy (local or national). Networks and clusters can help with the diffusion of the innovation. We have seen a lot of focus and financing in the development of such networks. Yet, there is still a lot that needs to be improved both by networks, universities and governments in order to fully materialize the potential of start-ups. Access to innovation is closely linked with access to knowledge ${ }^{60}$ whereas creators and inventors continue to feel they need to protect and keep behind a closed door their innovation in order to secure necessary legal protection and consequently achieve financial gain. It is for a further discussion that intellectual property scholars have already dived into, to streamline the protection of invention and efficiently acknowledge the rights of the inventors, while considering the rights of the society. ${ }^{61}$

\subsubsection{Technology and sustainability}

Reviewing start-up activities across the world over the past couple of years, the focus of their activities is undeniably on development or appli-

57 Everett M Rogers, Diffusion of Innovation (3rd edn, The Free Press 1982).

58 Christopher Freeman, Luc Soete and John Clark, Unemployment and Technical Innovation: A Study of Long Waves and Economic Development (F Pinter 1982) 65.

59 ibid.

60 Hannu Wager and Jayashree Watal, 'Human Rights and International Intellectual Property Law' in Christophe Geiger (ed.), Research Handbook on Human Rights and Property (Edward Elgar 2015); Caterina Sganga, 'Right to Culture and Copyright: Participation and Access' in Christophe Geiger (ed.), Research Handbook on Human Rights and Property (Edward Elgar 2015).

${ }_{61}$ See e.g. Caterina Sganga, Propertizing European Copyright: History, Challenges and Opportunities (Edward Elgar 2018); Mark Perry, 'The Changing Face of Intellectual Property: Global Forces and Compliance' in Mark Perry (ed.), Global Governance of Intellectual Property in the 21st Century (Springer 2016); Yafit Lev Arez and Katherine J Strandburg, 'Regulation and Innovation: Approaching Market Failure from Both Sides' (2019) https://papers.ssrn.com/sol3/papers.cfm ?abstract_id=3462522 accessed 10 March 2020. 
cation of new technology as well as sustainability in various industries. ${ }^{62}$ This trend is present, as many recognize the potential of innovation for sustainability, both from business as well as an environmental perspective. This attention to sustainability is not accidental. Aside from a greater interest and awareness of climate change, there have been several international and regional policy initiatives that have supported and emphasized policy and financial support for these new endeavours, recognizing the potential and relevance of start-ups in developing new business models and sustainable processes and operations.

The 2030 Agenda for Sustainable Development, adopted by UN Member States in September 2015, emphasized the role of entrepreneurship in sustainable development. ${ }^{63}$ Two goals, particularly Goal 4 (ensure inclusive and equitable quality education and promote lifelong learning opportunities for all) and Goal 8 (promote sustained, inclusive, and sustainable economic growth, full and productive employment, and decent work for all) have been emphasized. More specifically, the target 8.3 calls for the promotion of development-oriented policies that support decent job creation, entrepreneurship, creativity, and innovation and encourage the formalization and growth of SMEs. ${ }^{64}$ The UN, in the 2030 Development Agenda, envisions the complementing effect of entrepreneurs, innovation and sustainable development, recognizing the potential of start-ups.

Similarly, UNCTAD developed the Entrepreneurship Policy Framework in 2012 (EPF). ${ }^{65}$ The EPF suggests policy options and recommendations in six priority policy areas that have a direct impact on entrepreneurial

62 Increased interest is in cleantech, start-ups focusing on environmental solutions, technological innovation within the eco spin, food sustainability etc.; See e.g. Mark Tercek, 'Techstars Sustainability Accelerator: 10 Start-Ups Driving Innovation for the Planet' (Forbes, 7 August 2018) https://www .forbes.com/sites/marktercek/2018/08/07/techstars-sustainability-accelerator-10-start-ups-driving -innovation-for-the-planet/\#442d1dc19e98 accessed 12 March 2020; Tina Wung, '24 Innovative Startups Making Climate Change Impact in 2019' (RocketSpace, 4 October 2019) https://www .rocketspace.com/corporate-innovation/24-innovative-startups-making-climate-change-impact-in -2019 accessed 12 March 2020; Ranjay Gulati, 'The Soul of a Start-Up' (Harvard Business Review, July-August 2019) https://hbr.org/2019/07/the-soul-of-a-start-up accessed 12 March 2020.

63 United Nations, 'Transforming our World: The 2030 Agenda for Sustainable Development' (United Nations 2015) https://sustainabledevelopment.un.org/post2015/transformingourworld accessed 10 March 2020.

64 ibid.

65 UNCTAD, 'Entrepreneurship Policy Framework and Implementation Guidance' (2012) https:// unctad.org/en/PublicationsLibrary/diaeed2012d1_en.pdf accessed 9 March 2020. 
activity: (1) formulating national entrepreneurship strategies; (2) optimizing the regulatory environment; (3) enhancing entrepreneurship education and skills development; (4) facilitating technology exchanges and innovation; (5) improving access to finance; and (6) promoting awareness and networking. ${ }^{66}$ Reading through the EPF and the policy recommendation, the thread is clear: entrepreneurship, innovation, technology and sustainability.

Start-ups can contribute not only to technology development, but also to sustainable development and the achievement of social development goals, as adopted by the UN General Assembly. ${ }^{67}$ Adopting holistic regulatory policies in the light of the above recommendations combined with the analysis that this book offers can create a conducive start-up environment which takes into account sustainable and inclusive business models.

\subsection{Conclusion}

Studies have been published that show a clear relationship between start-up activity and national economic development and competitiveness. ${ }^{68}$ There is evidence that the relationship between entrepreneurship and economic development largely depends on the national economic environment, which is shaped by economic, institutional and socio-cultural factors ${ }^{69}$ combined with regulatory and tax frameworks. Start-ups with their innovative and entrepreneurial activity represent the key element for economic growth in developed countries ${ }^{70}$ and developing countries. ${ }^{71}$ It should be in the interest of all to attempt to create

66 UNCTAD (n 65).

67 ibid.

68 Salustiano Martínez-Fierro, José María Biedma-Ferrer, José Ruiz-Navarro, 'Impact of High-growth Start-ups on Entrepreneurial Environment Based on the Level of National Economic Development' [2019] Business Strategy and the Environment 1-14.

${ }_{69}$ See e.g. José Ernesto Amorós, Cristóbal Fernández and Juan Tapia, 'Quantifying the Relationship between Entrepreneurship and Competitiveness Development Stages in Latin America’ [2012] 8(3) International Entrepreneurship and Management Journal 249-70; Sander Wennekers, André Van Stel, Martin Carree and Roy Thurik, 'The Relationship between Entrepreneurship and Economic Development: Is it U-shaped?' [2010] 6(3) Foundations and Trends in Entrepreneurship 167-237.

70 Magnus Henrekson and Dan Johansson, 'Gazelles as Job Creators: A Survey and Interpretation of the Evidence’ [2010] 35 Small Business Economics 227-244.

71 UNCTAD (n 65). 
a pro start-up environment where entrepreneurship, innovation and sustainability can be nurtured. The following chapters provide an insight into a variety of regulatory frameworks across the world that have proven successful. 